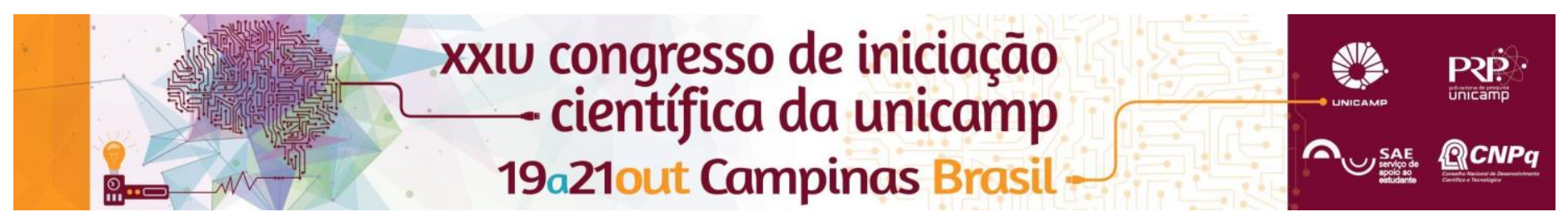

\title{
Sistemas microfluídicos para incorporação de DNA em nanoparticulas lipídicas sólidas
}

\author{
Karolina R. Costa*, Allan Radaic, Tiago A. Balbino, Marcelo. B. De Jesus, Lucimara. G. De La Torre
}

\section{Resumo}

Este trabalho visou o desenvolvimento de sistemas microfluídicos para complexação eletrostática entre nanopartículas lipídica sólidas (SLNs) e DNA para aplicações em terapia gênica.

\section{Palavras-chave:}

sistemas microfluídicos, nanopartículas lipídicas sólidas, terapia gênica

\section{Introdução}

Terapia gênica refere-se à inserção de ácidos nucleicos em células-alvo com consequente expressão do material genético modificado. Para que a entrega do material genético seja eficiente, são necessários vetores capazes de transferir o gene de interesse para o interior das células (transfecção). ${ }^{1}$ Nanopartículas lipídicas sólidas (SLNs) são sistemas coloidais de núcleo hidrofóbico composto por lipídeos sólidos a temperatura ambiente. Possuem alta estabilidade e natureza catiônica, o que permite o carreamento de ácidos nucléicos ${ }^{2}$.

A microfluidica visa processar pequenas quantidades de fluidos usando canais com dimensões de micrômetros. O ambiente nesses sistemas permite controle preciso e otimização da produção de carreadores de genes.

O objetivo deste trabalho foi investigar a complexação eletrostática entre DNA e SLNs usando microdispositivos de focalização hidrodinâmica, em diferentes razões de carga lipídio catiônico/DNA.

\section{Resultados e Discussão}

Os dispositivos microfluídicos foram obtidos por técnicas de fotolitografia macia. As SLNs foram formadas de uma microemulsão, seguida por uma etapa de extrusão para a redução e homogeneização de tamanho de partícula.

As amostras de SLNs apresentaram relativa baixa polidispersidade de $0,13 \pm 0,02$, diâmetro médio de $103,8 \pm 0,2 \mathrm{~nm}$, e potencial zeta de $+60,8 \pm 3,9 \mathrm{mV}$.

Complexos entre DNA e SLNs foram obtidos utilizando o método convencional bulk e dispositivos microfluídicos com microcanal central simples e com percurso.

Os complexos formados pelo método convencional apresentaram diminuição no seu diâmetro médio com o aumento na concentração de DNA na amostra. Enquanto a polidispersidade não apresentou variações significativas nas condições avaliadas. O potencial zeta apresentou-se positivo, o que viabiliza assim o carreamento do material genético para o interior de células.

As características físico-químicas dos complexos produzidos utilizando os dispositivos microfluídicos podem ser observados na Tabela 1.

Tabela 1. Características físico-químicas dos complexos entre SLNs e DNA em diferentes razões molares de cargas positivas e negativas (N/P) obtidos pelo dispositivo microfluídicos simples.

\begin{tabular}{|c|c|c|c|}
\hline $\begin{array}{c}\mathrm{N} / \\
\mathrm{P}\end{array}$ & $\begin{array}{c}\text { Diâmetro } \\
( \pm \mathrm{SD}) \mathrm{nm}\end{array}$ & $\begin{array}{c}\text { Polidispersidade } \\
\text { Pdl (i) }\end{array}$ & $\begin{array}{c}\text { Potencial Zeta } \\
( \pm \mathrm{SD}) \mathrm{mV}\end{array}$ \\
\hline 5 & $265,2 \pm 3,1$ & $0,28 \pm 0,04$ & $32,5 \pm 1,4$ \\
\hline 10 & $158,5 \pm 166$ & $00,21 \pm 0,02$ & $39,6 \pm 2,2$ \\
\hline
\end{tabular}

Tabela 2. Características físico-químicas dos complexos entre SLNs e DNA em diferentes razões molares de cargas positivas e negativas (N/P) obtidos pelo dispositivo microfluídicos com barreiras (dentado).

\begin{tabular}{|c|c|c|c|}
\hline $\begin{array}{c}\mathrm{N} / \\
\mathrm{P}\end{array}$ & $\begin{array}{c}\text { Diâmetro } \\
( \pm \mathrm{SD}) \mathrm{nm}\end{array}$ & $\begin{array}{c}\text { Polidispersidade } \\
\text { Pdl (i) }\end{array}$ & $\begin{array}{c}\text { Potencial Zeta } \\
( \pm \mathrm{SD}) \mathrm{mV}\end{array}$ \\
\hline 5 & $157,1 \pm 0,6$ & $0,20 \pm 0,02$ & $44,6 \pm 3,5$ \\
\hline 10 & $133,9 \pm 1,2$ & $0,24 \pm 0,02$ & $56,1 \pm 2,0$ \\
\hline
\end{tabular}

(i) Pdl - polidispersidade das amostras, varia em ordem crescente entre 0 e 1.

(ii) Diâmetro médio equivale ao "z-average".

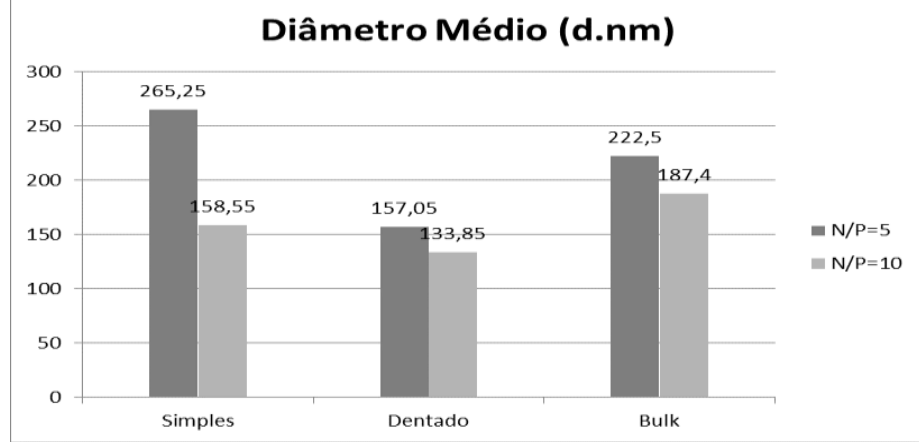

Figura 1. Relação entre o diâmetro médio e razão de carga dos complexos produzidos por diferentes processos de complexação.

\section{Conclusões}

Os complexos obtidos através dos dispositivos microfluídicos com percurso apresentaram menor diâmetro médio que os obtidos em bulk e dispositivo simples, o que indica que o percurso presente no dispositivo possibilitou um efeito de mistura mais efetivo. Analisando as razões de carga, é possível perceber que para a condição de 5 o complexo pelo processo convencional bulk apresentou menor diâmetro que dispositivo simples, o que não ocorreu na razão de carga de 10. Quanto a polidispersidade, essa se manteve baixa em todos os complexos formados. O potencial zeta se manteve positivo e sofreu pouca variação.

\section{Agradecimentos}

Meus agradecimentos ao LNNano (CNPEM), Unicamp (IB e FEQ) e a instituição de fomento CNPq.

${ }^{1}$ De La Torre, L.G. et al. Synergy between structural stability and DNA

Colloids and Surfaces B: Biointerfaces, v. 73, 175-184, 2009.

${ }^{2}$ Müller, R.B. et al. Solid lipid nanoparticles (SLN) and nanostructured lipid carriers (NLC) in cosmetic and dermatological preparations. Adv Drug Del Rev 54: S131-S155. 2002 